\title{
A HARD SAYING
}

QURELY of all the hard sayings in the Gospel, $D$ the words at the end of the parable of the Good Samaritan are the hardest: "Go, and do thou in like manner '-Vade, et tu fac similiter.

The story itself is plain and simple; none of the parables of Christ is more familiar. The very phrase, 'a good Samaritan,' has passed into the language. And yet, is there anything harder for the average man than the concluding injunction, ' $\mathrm{Go}$, and do thou in like manner'? Its very directness leaves no loophole for misunderstanding or evasion. There is no suggestion here of a counsel of perfection. It is just an instruction in neighbourly conduct, and an instruction exceedingly hard to obey.

The Samaritan adopts a complete stranger, whom he finds in distress, and recognizing the wounded man as a neighbour, promptly provides him with hospitality; thereby inventing a home for the homeless, and for one person at least solving the housing problem. 'Go, and do thou likewise,' declares the Saviour of the World!

The clergy had passed the injured man by. Perhaps they blamed 'the system,' social and economic, that allows wounded persons to lie homeless and destitute by the roadside. Possibly they blamed the authorities, to whom they paid rates and taxes, for not keeping better order and suppressing highway robbery. In any case, the injured man was quite unknown to them. Certainly he was not a regular attendant at church, or they would have identified him. It is impossible to suppose that a sidesman or a seatholder found lying in the gutter would not be recognised and assisted. Whoever this urhappy man 


\section{Blackfriars}

might be, it was not clear how he came to have fallen so low. Possibly he was drunk. Probably he had got into bad company. Why had he fallen among thieves? There was nothing in his appearance to suggest that he was a mere victim of circumstances. The clergy passed him by : they had their own work to do. The presbytery is not a lodging-house or a casualty clearing station. Even our monasteries, convents and priories cannot extend hospitality to stray and unknown persons in distress, or find room for every vagrant fallen by the way. "To him that hath shall be given'-hospitality must be limited to the respectable, to those neither destitute nor homeless, to the honoured guest. Prudence and commonsense approve the attitude of the priest and levite.

And yet Christ, though He utters no word of reproach against the priest and levite, tells us not to imitate the clergy in this matter, but to do as the Samaritan did: the Samaritan-separatist and perhaps heretical.

The Samaritan knew no more of the fallen man than did the priest and levite. He picks him up without enquiring into his character, ministers to his immediate necessities, takes him to the nearest hotel, and relieves his distress out of his own pocket. All this indiscriminate assistance is quite against the wellknown principles of the Charity Organisation Society. How could the Samaritan know that the injured man had not brought his misfortunes on himself by his own fault? And in spite of the C.O.S. and its kindred societies, there are the plain words of the Gospel: 'Go, and do thou in like manner.'

Surely the hardest of all hard sayings! We cannot take sick and destitute strangers, casually picked up by the way-side, and put them in our best spare bedroom. The servants wouldn't stand it, and the people living next door would think it odd. Besides, 


\section{$A$ Hard Saying}

we haven't always got room for our own particular friends. Hospitality may be all very well in Eastern countries, but its quite another matter in England. As to personal service and providing food and a night's lodging and medical attendance for a man picked up unconscious in the street-how can it be thought of? What are hospitals and workhouse infirmaries for? As Scrooge quite reasonably observed, 'Are there no prisons? are there no workhouses?' If the Samaritan had enjoyed the advantage of studying our many modern handbooks on social welfare, he could have learnt a better plan. He acted on impulse, doubtless a good impulse, but still impulse. A quiet and earnest examination of the methods of experienced social workers would have taught the Samaritan that system is needed in well-regulated charitable relief; and that hasty and ill-considered action, though it may save a man's life and put him on his feet again, is by no means desirable as a general rule. For all the Samaritan could tell, that wounded man might have fallen among thieves before, and though temporarily restored, there was nothing to show that he would not succumb to adversity again. Statistics prove conclusively that haphazard help does not diminish the sum total of destitution. And then there are always the ' deserving poor' cases carefully investigated, indexed and fully recorded, with all details as to their requirements properly noted down on approved forms. These 'deserving poor' surely have the prior claim? Admittedly the Samaritan acted on a good impulse, but he acted without the knowledge of the trained expert who "works among the poor.' Beatus qui intelligit super egenum et pauperem.

And still the finger of Christ points to the Samaritan, and bids us 'Go, and do thou in like manner.'

So vast is the library on the subject of social welfare 


\section{Blackfriars}

that a life-time may be spent reading the books. The Samaritan would have been floored on coming face to face with a wounded, destitute and homeless stranger had he made an adequate study of these volumes with their problems and solutions. With mind confused and distracted by the exceedingly varied advice, he could but have rendered 'first aid' of a necessary but perfunctory character. As it was, the only problem before the Samaritan, ignorant perchance of social science and statistics, presented no difficulties: how quickly and effectively could he succour in friendly fashion a neighbour who had fallen into the hands of thieves.

And Christ says the Samaritan's line is the right one, and the line for others to take- ' Go, and do thou in like manner.'

Does the injunction apply to Christians? Or was it only intended for the particular person addressed? May we, after all, relegate it to the counsels of perfection? Or are we bound to give, in friendly fashion, personal service and a portion of our scanty means to neighbours in distress whom we find on life's highway? (There is nothing to suggest that the Samaritan was a knight errant who went about looking for people in distress. Still less may we infer that the Samaritan objected to the road being cleared of robbers and made safe for travellers on the ground that so radical a reform would destroy the opportunities of charity.)

'Go, and do thou in like manner.' The words are the words of Christ, not airily to be dismissed as words without meaning, or without application in these enlightened latter days. Robbers still infest the paths of man, and their victims are yet found faint and bruised by the road-side.

But what do the words mean? and who will interpret this hard saying? Joseph Clayton. 